\title{
Study of the Opuntia ficus indica and Its Radioactive Potassium Content using the Gamma Spectrometry
}

\author{
Guillermo Espinosa $^{1}$ José-Ignacio Golzarri $^{1}$ and Edgar Padilla-Soriano ${ }^{2}$ \\ 1. Physics Institute, National Autonomous University of Mexico (UNAM), Mexico City 04520, Mexico \\ 2. Chemistry Faculty, National Autonomous University of Mexico (UNAM), Mexico City 04510, Mexico
}

\begin{abstract}
Mexico is one of the largest producers of nopal (Opuntia ficus indica). This "vegetable" is consumed on a daily basis by the Mexican population, being a source of food nutrients. Among its benefits, it is considered the content of potassium, which is essential for human life and health. In this study, it analyzes the content of potassium of the Mexican cactus (Opuntia ficus indica) grown in 5 different regions in the Mexican Basin, where 67\% of the nopal is produced for human consumption. The used methodology is gamma spectrometry with Hyperpure Germanium detector (HPGe) and Multichannel Analyzer (MCA) with Maestro ${ }^{\circledR}$ software. The results show interesting aspects on the concentration of potassium in the nopal. This concentration will primarily depend on: (a) the geological characteristics of the location where the nopal was grows; (b) that potassium concentrations may vary substantially from a region to another, with the same species of nopal as a reference and (c) that this concentration may also vary from one growing season to another.
\end{abstract}

Key words: Potassium, nopal (Opuntia ficus indica), gamma spectrometry, K-40, HPGe.

\section{Introduction}

In recent years, it has attributed vital importance to the nutrient composition of foods. According to this, foods affect the health of living beings in different forms. This has promoted to researchers great interest in the study of the effects caused by the excess or deficiency of some nutrients derived from the diet and, on the other hand, has prompted the search for ways to counteract the lack of avoiding excess nutrients involved with food. Because of this, search and optimize new analytical techniques and diversify existing to evaluate the nutritional composition of foods has taken great global concern.

The aim of this paper is to present the study of a technique based on gamma spectroscopy for quantification of elemental potassium in foods that provide accurate and reliable results. In this study, samples of vegetables in Mexico (nopal: Opuntia ficus indica) were analyzed by means of the detection and

Corresponding author: Guillermo Espinosa, Ph.D., main research field: radiation physics. quantification of potassium-40 $\left({ }^{40} \mathrm{~K}\right)$, radioactive isotope content of natural and innate in any food or product with potassium [1]. The determination is based on measuring the gamma radiation emitted naturally by the food immersed in potassium, this radiation is caused by the radioactive decay of potassium nuclide $\left({ }^{40} \mathrm{~K}\right)(0.0118 \%$ of potassium) per unit time. So, when considering the balance between secular nuclides daughters and parents of this radioisotope, the rate of emission of gamma radiation is proportional to the amount of ${ }^{40} \mathrm{~K}$ in the study sample. From the ratio of ${ }^{40} \mathrm{~K}$ in the sample (specific activity of the sample) and the specific activity of potassium theoretically established, one can determine the total elemental concentration of potassium in the sample.

Although it is well known that to identify and quantify the potassium in food samples [2-6], several methods can be used, but the nuclear ones are more commons these days.

This study attempts to publicize and promote the gamma spectroscopy as an alternative and modern 
analysis method, offers great advantages over other methods such as a non-destructive technique, which does not require complex sample preparation and allows results with high reliability and accuracy.

Potassium is an essential dietary mineral, required to sustain biological processes. It constitutes $5 \%$ of the total mineral content of the human body [7]. Natural potassium comprises the isotopes ${ }^{39} \mathrm{~K},{ }^{40} \mathrm{~K}$ and ${ }^{41} \mathrm{~K}$, where ${ }^{39} \mathrm{~K}$ and ${ }^{41} \mathrm{~K}$ are stable elements and ${ }^{40} \mathrm{~K}$ is a radioactive isotope (isotopic abundance $0.0118 \%$ ) with a half-life of $1.28 \times 10^{9}$ years, and is the most abundant radioactive substance in the human body. ${ }^{40} \mathrm{~K}$ decays to ${ }^{40} \mathrm{Ca}$ by $\beta$ decay (89\%) and to ${ }^{40} \mathrm{Ar}$ by $\beta+$ decay (11\%), the latter associated with the emission of a gamma ray of $1,462 \mathrm{keV}$ which is used for the determination of ${ }^{40} \mathrm{~K}$ concentration [8].

HPGe gamma spectrometry is a nondestructive analytical method and used here for the analysis of ${ }^{40} \mathrm{~K}$ in nopal. The secular equilibrium between daughter nuclides and the naturally occurring parents implies that the gamma ray emission rate for the decay to ${ }^{40} \mathrm{Ar}$ is proportional to the amount of ${ }^{40} \mathrm{~K}$ in nopal [9]. The aim of this study is to assess the potassium concentrations in Mexican nopal.

\section{Methodology}

\subsection{Specific Activity of Potassium}

The specific activity of potassium (number of disintegrations per second per gram) is given by Eq. (1), where $N_{A}=$ Avogadro's constant $\left(6.02 \times 10^{23}\right.$ $\left.\mathrm{mol}^{-1}\right), a$ isotopic abundance of ${ }^{40} \mathrm{~K}(0.0118 \%), M_{W}$ $=$ molecular weight of potassium $(39.1 \mathrm{~g} / \mathrm{mol})$ and $T_{1 / 2}$ = half-life of ${ }^{40} \mathrm{~K}\left(1.27 \times 10^{9} \mathrm{y}\right)[10,11]$.

$$
A_{c}=\frac{N_{A} a \ln 2}{100 M_{W} T_{1 / 2}}=31.19^{B q} / g K
$$

\subsection{Detection Efficiency}

The detection efficiency $E_{f f}$ is given by the number of counts per second per gram from the $\mathrm{KCl}$ standard divided by the specific activity of potassium $A_{c}$ in Eq. (2), where $\mathrm{C}_{\mathrm{st}}=$ total counts $(1,461 \mathrm{keV}$ peak) from the standard (including background); $A_{\gamma}=$ percentage gamma radiation emission from ${ }^{40} \mathrm{Ar} ; C_{B}=$ total counts from the background radiation, $M_{K S t}=$ mass of $\mathrm{K}$ in the $\mathrm{KCl}$ standard (g) and $T=$ analysis time (s).

$$
\begin{gathered}
E_{f f}=\frac{C_{s t}-C_{B}}{A_{\gamma} A_{c} M_{K S t} T}=\frac{120784-5832}{31.19 \times 0.11 \times 192.27 \times 80000}= \\
=0.0022=0.22 \%
\end{gathered}
$$

The specific activity of a particular sample $A_{S}$ is given by Eq. (3), where $C_{S}=$ total count $(1,461 \mathrm{keV}$ peak) from the sample; $C_{B}=$ total counts from the background radiation; $W_{S}=$ mass of the sample (g); $T$ = analysis time (s) and $E_{f f}=$ detection efficiency [12].

$$
A_{s}=\frac{\left(C s-C_{B}\right) / T}{W_{s} E_{f f} A_{\gamma}}
$$

Finally, dividing the specific activity of a sample $A_{S}$ by the specific activity of potassium $A_{c}$ yields the concentration of potassium of the sample (Eq. (4)). Here the authors express the results as a percentage, or, equivalently, the number of grams of potassium per $100 \mathrm{~g}$ (or $\mathrm{mL}$ ) of sample.

$$
\% K=\frac{A_{s}}{A_{c}} \times 100
$$

\subsection{Sample Description}

The nopal (Opuntia spp.) is a plant of the family Cactaceae Opuntia, which is produced mainly in dry tempered, semi-arid and tropical zones. Being the cactus species, Opuntia ficus indica is commonly known as "nopal". The first indication in the history of mankind on the use of nopal attributed to the Mesoamerican man, dating from 7,000 BC to 9,000 BC according to archaeological discoveries conducted by Mac Neish, R. S. [13] in semiarid regions of Tamaulipas and the Valley of Tehuacan, Puebla.

\subsection{Sample Selection}

In the selection of the samples analyzed, the metropolitan area of Mexico valley was chosen 
because it contributes $52.7 \%$ of total production in Mexico and is further characterized by production of nopal Opuntia ficus indica. All samples were collected in 2012. Samples of the nopal plants are shown in Fig. 1.

The location where the nopal are produced are shown in Fig. 2, and the location names, political demarcations, metropolitan area of Mexico, elevation above sea level and geographic coordinates are shown in Table 1.

\section{Instrumentation}

\subsection{Sample Preparation}

The nopal samples did not have a special preparation, only each fresh nopal was cut in small pieces. This aimed to fill the Marinelli container with the same weight of material of each sample, and keep the same detection geometry in all the samples.

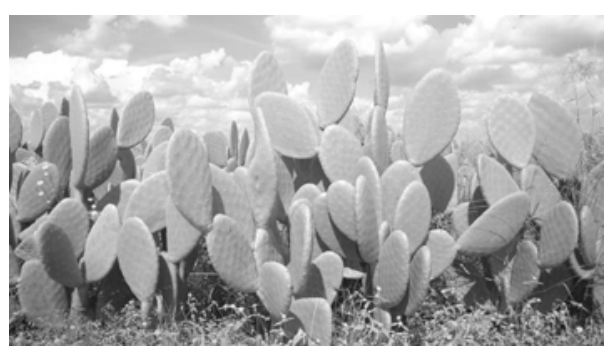

(a)

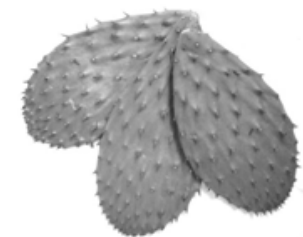

(b)

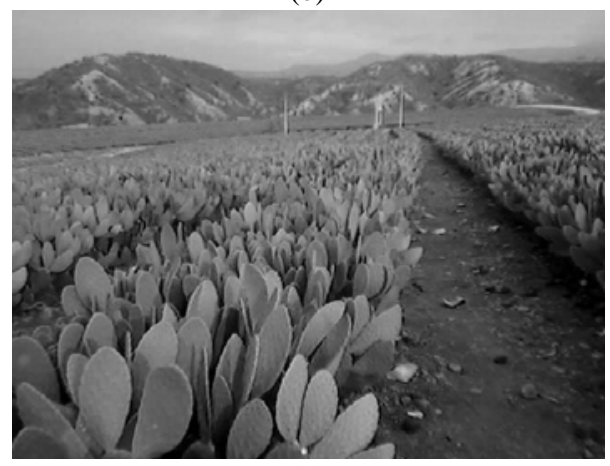

(c)

Fig. 1 Samples of nopal plants: (a) nopal plant; (b) nopal leaves and (c) nopal plantations.

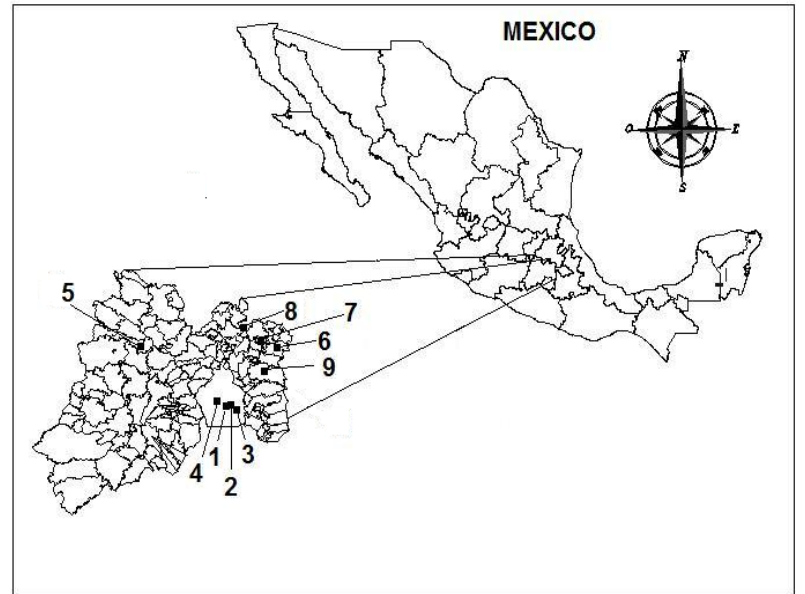

Fig. 2 Map of the studied region, with the locations of the nopal production: Milpa Alta (1-3), Xochimilco (4), Atlacomulco (5), Tizayuca (6), Zumpango (7-8) and Texcoco (9).

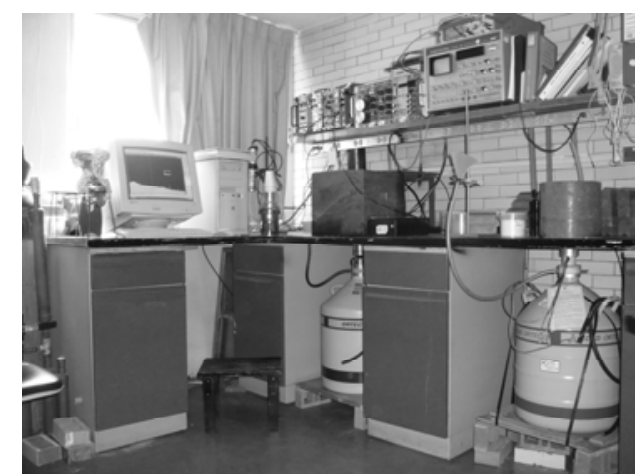

Fig. 3 Picture of the HPGe and MCA used system.

The equipment used included an EG \& G Ortec ${ }^{\circledR}$ Hyper Pure Germanium (HPGe) detector, an Ortec $439^{\circledR}$ bias supply, an Ortec $570^{\circledR}$ amplifier, an Ortec ACE $4 \mathrm{~K}^{\circledR}$ multichannel card and a PC. The gamma ray spectra were obtained using the Maestro $2^{\circledR}$ program and analyzed using the Gamma Vision program. A 36.4 $\times 33.6 \times 35 \mathrm{~cm}$ old lead box of wall thickness $7.5 \mathrm{~cm}$ was used to reduce background radiation [7]. Old lead was used to ensure better and low background. In Fig. 3, it showed the picture of the HPGe and multichannel analysis system used PAD-IFUNAM.

\subsection{Determination of the Background}

In order to determine the analysis system background, five spectra of $24 \mathrm{~h}$ were taken with an empty Marinelli. The environmental ${ }^{40} \mathrm{~K}$ photopeak of the background spectrum appears as usual. 
Table 1 Location names, political demarcations (locality and municipality), state of the republic state, elevation above sea level and geographic coordinates.

\begin{tabular}{|c|c|c|c|c|c|c|}
\hline \multirow{2}{*}{ Sample ID } & \multirow{2}{*}{ Location name } & \multicolumn{3}{|l|}{ Origin of the samples } & \multirow{2}{*}{$\begin{array}{l}\text { Elevation above sea } \\
\text { level (m) }\end{array}$} & \multirow{2}{*}{$\begin{array}{l}\text { Geographic } \\
\text { coordinates lon./lat. }\end{array}$} \\
\hline & & Locality & Municipality & State & & \\
\hline 1 & Milpa Alta 1 & San Lorenzo Tlacoyucan & \multirow{3}{*}{ Milpa Alta } & \multirow{3}{*}{ Mexico city } & \multirow{3}{*}{2,600} & \multirow{3}{*}{$\begin{array}{l}19^{\circ} 60^{\prime} \mathrm{N} \\
99^{\circ} 00^{\prime} \mathrm{W}\end{array}$} \\
\hline 2 & Milpa Alta 2 & Villa Milpa Alta & & & & \\
\hline 3 & Milpa Alta 3 & Villa Milpa Alta & & & & \\
\hline 4 & Xochimilco & Santa Cruz Acalpixcan & Xochimilco & Mexico city & 2,240 & $\begin{array}{l}19^{\circ} 27^{\prime} \mathrm{N} \\
99^{\circ} 12^{\prime} \mathrm{W}\end{array}$ \\
\hline 5 & Atlacomulco & Atlacomulco & Atlacomulco & \begin{tabular}{|l} 
Estado de \\
México
\end{tabular} & 2,578 & \begin{tabular}{|l|}
$19^{\circ} 48^{\prime} \mathrm{N}$ \\
$99^{\circ} 51^{\prime} \mathrm{W}$
\end{tabular} \\
\hline 6 & \begin{tabular}{|l|}
$\begin{array}{l}\text { Nopal Tizayuca } \\
\text { (Silvestre) }\end{array}$ \\
\end{tabular} & Emiliano Zapata & Tizayuca & $\begin{array}{l}\text { Hidalgo, } \\
\text { México. }\end{array}$ & 2,240 & $\begin{array}{l}19^{\circ} 20^{\prime} \mathrm{N} \\
99^{\circ} 11^{\prime} \mathrm{W}\end{array}$ \\
\hline 7 & Otumba & Otumba & Zumpango & \begin{tabular}{|l|} 
Estado de \\
México \\
\end{tabular} & 2,760 & \begin{tabular}{|l|}
$19^{\circ} 37^{\prime} \mathrm{N}$ \\
$98^{\circ} 40^{\prime} \mathrm{W}$ \\
\end{tabular} \\
\hline 8 & San Martin & San Martin de las Pirámides & Zumpango & $\begin{array}{l}\text { Estado de } \\
\text { México }\end{array}$ & 2,300 & $\begin{array}{l}19^{\circ} 37^{\prime} \mathrm{N} \\
98^{\circ} 45^{\prime} \mathrm{W}\end{array}$ \\
\hline 9 & Texсосо & Техсосо & Техсосо & $\begin{array}{l}\text { Estado de } \\
\text { México }\end{array}$ & 2,250 & $\begin{array}{l}19^{\circ} 25^{\prime} \mathrm{N} \\
98^{\circ} 55^{\prime} \mathrm{W}\end{array}$ \\
\hline
\end{tabular}

\subsection{Energy Calibration}

The HPGe analysis system was calibrated in energy using the Gamma Vision program with the radioactive sources of ${ }^{241} \mathrm{Am}(60 \mathrm{keV}),{ }^{137} \mathrm{Cs}(662 \mathrm{keV})$ and ${ }^{60} \mathrm{Co}$ $(1,173 \mathrm{keV}$ and $1,332 \mathrm{keV})$ and natural potassium ${ }^{40} \mathrm{~K}$ $(1,460 \mathrm{keV})$.

\subsection{KCl Standard Calibration}

The potassium standard used was $366.6 \mathrm{~g}$ of potassium chloride crystal assayed by the supplier Backer, J. T. ${ }^{\mathrm{TM}}$. The $\mathrm{KCl}$ was placed inside the $500 \mathrm{~mL}$ Marinelli beaker and analyzed with the spectrometer system over $24 \mathrm{~h}$. The energy of the photopeak was $1,460 \mathrm{keV}$ and the energy resolution (FWHM) was $2.5 \mathrm{keV}$.

\subsection{Measurement Conditions}

The measurements of the different samples were carried out under identical conditions. The nopal was distributed homogenously inside the Marinelli beaker and covered the top of the detector. The relevant detection efficiency of $0.22 \%$ was calculated above. The different samples of nopal were also analyzed to determine their potassium concentrations.

\section{Results and Discussion}

In Fig. 4, it showed the gamma spectra of potassium $\left({ }^{40} \mathrm{~K}\right)$ of the nopal samples (1 to 9 ), and can observe each one in different potassium concentrations. The photopeak analysis was done using ORTEC-MAESTRO $^{\circledR}$ software, and the proposed methodology and calculation on the previous section.

Table 2 shows the numerical results of the gamma spectrometry analysis content: sample code, sample weight, net area, potassium contents in the sample $\left(\mathrm{Bq} / \mathrm{m}^{3}\right)$ and normalized content of potassium ( $\mathrm{mg}$ of potassium per $100 \mathrm{~g}$ of sample). This last column content information is presented in Fig. 5. As can be observed in the Fig. 5, the concentration of potassium is different in each one of the samples studied, from $330.6 \mathrm{mg} / 100 \mathrm{~g}$ of potassium (the highest) to 37.9 $\mathrm{mg} / 100 \mathrm{~g}$ (the lowest). The potassium content in the nopal is independent to the kind of plant. The potassium concentration will depend on the ground location and its natural compounds in the soil.

For example, the nopal samples from the Milpa Alta (1-3) location have variation of potassium contents, the zone to zone of production, and shown a big differences with other locations as it is between nopal from Texcoco (9) and nopal from Xochimilco (4).

This work also shows that consuming of nopal as ingest of potassium will be very dependent of the content of potassium in the nopal, in turn, this will depend on the region or area where it grew. 

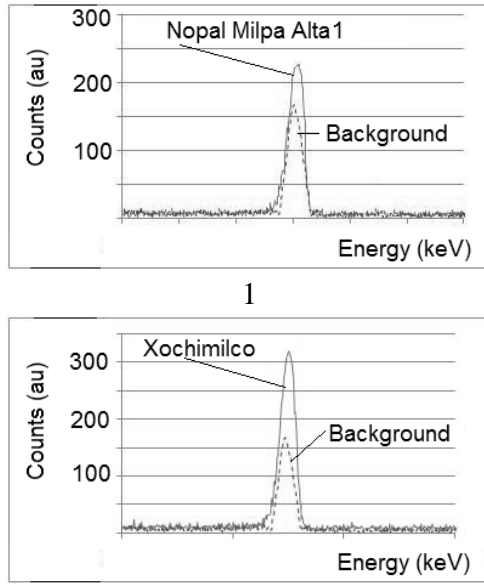

4

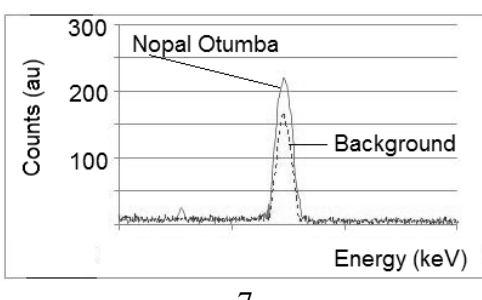

7

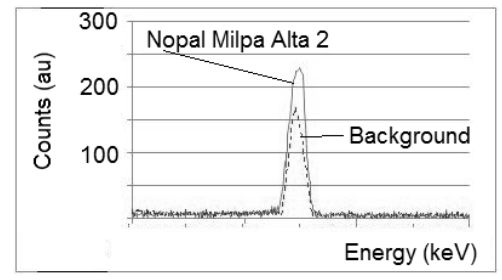

2

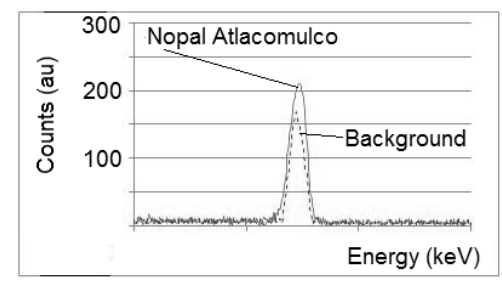

5

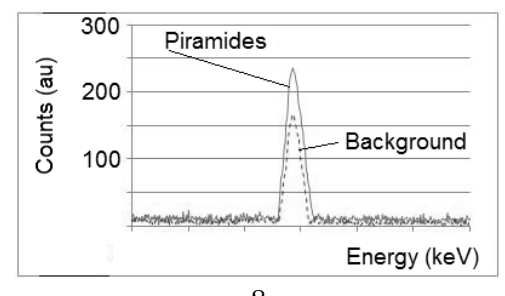

8

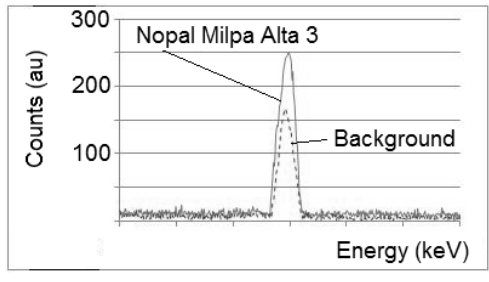

3

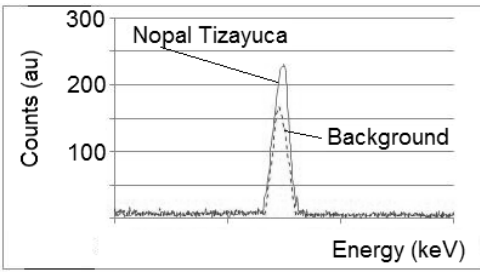

6

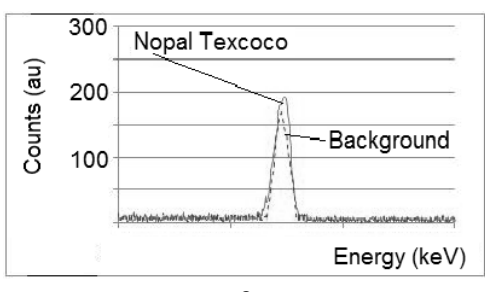

9

Fig. 4 Gamma spectra of each one of nopal samples in the ${ }^{40} \mathrm{~K}$ region $(1,460 \mathrm{keV})$.

Table 2 Results of the spectra analysis and the calculus of potassium content in the samples.

\begin{tabular}{lllll}
\hline Sample ID & Amount (g) & $\begin{array}{l}\text { Net area } \\
\text { (counts) }\end{array}$ & As nopal (Bq/g nopal) & mg K/100 g nopal \\
\hline 1 & $350 \pm 0.1$ & $380 \pm 5$ & 0.0571 & $183.2 \pm 2.4$ \\
2 & $350 \pm 0.1$ & $337 \pm 5$ & 0.0507 & $162.5 \pm 2.3$ \\
3 & $350 \pm 0.1$ & $441 \pm 8$ & 0.0664 & $212.8 \pm 3.8$ \\
4 & $350 \pm 0.1$ & $685 \pm 10$ & 0.1031 & $330.6 \pm 5.0$ \\
5 & $350 \pm 0.1$ & $187 \pm 4$ & 0.0280 & $89.9 \pm 1.6$ \\
6 & $350 \pm 0.1$ & $272 \pm 4$ & 0.0408 & $131.0 \pm 2.5$ \\
7 & $350 \pm 0.1$ & $190 \pm 3$ & 0.0285 & $91.5 \pm 1.4$ \\
8 & $350 \pm 0.1$ & $705 \pm 7$ & 0.0609 & $195.2 \pm 3.3$ \\
9 & $350 \pm 0.1$ & 0.0118 & $37.9 \pm 0.5$ \\
\hline
\end{tabular}

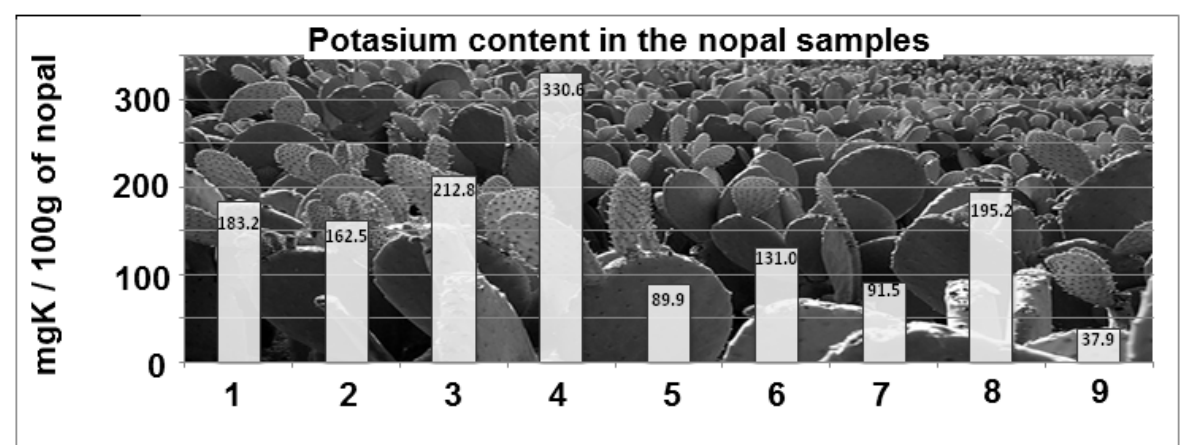

Fig. 5 Potassium content in the different varieties species of Mexican nopal samples. 


\section{Conclusions}

The analysis of potassium concentrations of foods and beverages is becoming more important in terms of both public health guidelines and policies, also the treatment or management of specific diseases. The gamma spectrometric analysis of the ${ }^{40} \mathrm{~K}$ and the total potassium in the samples is facilitated by the use of HPGe detectors and the automatic analysis software. The method is excellent, precise, highly reliable, non-destructive and requires less time and effort than conventional chemical analysis. It is a suitable analysis method for determining the potassium concentrations of a wide variety of beverages, seeds, grains, vegetables and other foods.

The potassium content variability found among the samples analyzed in this study can be attributed to different types of soils, and chemical compounds and amounts of potassium fertilizers are added in different nopal producing lands, but not by the species of plants by self.

\section{Acknowledgements}

The authors wish to thank to García, A., Gonzalez, N., Martinez, J., Novoa, L., Veytia, M., Huerta, A., and Chavarría, A. for their technical helps. This work was partially supported by PAPIIT-DGAPA-UNAM grants 1N103013 and IN103316.

\section{References}

[1] Brodsky, A. 1990. Handbook of Radiation Measurement and Protection, 3rd Edition. USA: CRC Press.

[2] Eisenbud, M., and Gesell, T. 1997. Environmental Radioactivity from Natural, Industrial and Military Sources. San Diego: Academic Press.

[3] Thulasi Brindha, J., Rajaram, S., and Kankan, V. 2007. "A Comparative Study of Body Potassium Contents in Males and Females at Kalpakkam (India).” Radiat. Prot.
Dosim. 123: 36-40.

[4] Argonne National Laboratory. 2005. "Human Health Fact Sheet.” EVS. Accessed February 4, 2016. http//www.remm.nlm.gov/ANL_ContaminantFactSheets_ All_070418.pdf.

[5] Navarrete, M., Campos, J., Martínez, T., and Cabrera, L. 2005. "Determination of Potassium Traces in Foodstuffs by Natural ${ }^{40} \mathrm{~K}$ Radiation.” J. Radioanal. Nucl. Chem. 265: 133-135.

[6] Espinosa, G., Hernandez-Ibinarriaga, I., and Golzarri, J. I. 2009. "An Analysis of the Potassium Concentrations of Soft Drinks by HPGe Gamma Spectrometry." $J$. Radioanal. Nucl. Chem. 282: 401-405.

[7] Espinosa, G., Golzarri, J. I., and Navarrete, M. 2016. "Determination of the Natural and Artificial Radioactivity of a Selection of Traditional Mexican Medicinal Herbs by Gamma Spectrometry.” J. Radioanal. Nucl. Chem. 307: 1717-1721.

[8] Mheemeed, A. K., Najam, L. A., and Hussein, A. K. 2014 "Transfer Factors of ${ }^{40} \mathrm{~K},{ }^{226} \mathrm{Ra},{ }^{232} \mathrm{Th}$ from Soil to Different Types of Local Vegetables, Radiation Hazard Indices and Their Anual Doses.” J. Radioanal. Nucl. Chem. 302: 87-96.

[9] Navarrete, J. M., Espinosa, G., Golzarri, J. I., Muller, G., Zuñiga, M. A., and Camacho, M. 2014. "Marine Sediments as a Radioactive Pollution Repository in the World.” J. Radioanal. Nucl. Chem. 299: 843-847.

[10] Navarrete, M., Zuñiga, M. A., Espinosa, G., and Golzarri, J. I. 2014. "Radioactive Contamination Factor (RCF) Obtained by Comparing Contaminant Radioactivity $\left({ }^{137} \mathrm{Cs}\right)$ with Natural Radioactivity $\left({ }^{40} \mathrm{~K}\right)$ in Marine Sediments Taken up from Mexican Sea Waters." World Journal of Natural Sciences and Technology 4: 158-162.

[11] Padilla-Soriano, E. 2013. "Study of the Potassium Content in Mexican Nopal (opuntia ficus indica) through Nuclear Techniques.” Ph.D. thesis, University of Mexico.

[12] Yoram, N. E. 1997. "Traceability in the Amount-of-Substance Analysis of Natural Potassium, Thorium and Uranium by the Method of Passive Gamma-Ray Spectroscopy.” Accred. Qual. Assur. 2: 193-198.

[13] Mac Neish, R. S., Nelken-Terner, A., and Weitlaner, I. 1969. "The Non-Ceramic Artifacts.” American Journal of Archaeology 73 (1): 101-104. 